\title{
Implementasi Bimbingan Kelompok Sebagai Usaha Untuk Meningkatkan Prestasi Belajar Ipa Materi Pernapasan Pada Siswa Kelas VIII B SMP Negeri 1 Sawit Kabupaten Boyolali Semester Genap Tahun Pelajaran 2017/2018
}

\section{Widhiani Purwaningsih}

\begin{abstract}
The purpose of this study was to determine the implementation of group guidance as an effort to improve the science learning achievement of respiratory material in the class VIII B of Junior High School 1 Sawit, Boyolali at the second semester of 2017/2018 academic year. The research method used is Classroom Action Research. The independent variable is the implementation of group guidance. Science learning achievement is the dependent variable. The population is class VIII B of Junior High School 1 Sawit, Boyolali at the second semester 2017/2018 academic year. How to take samples with the value of student test and direct supervision of the learning process, from counseling guidance teachers and homeroom teachers. Research result. Based on the results of learning research after application with the group guidance method can improve from the initial conditions to the second cycle. There was an increase in the average value of 71.09 to 79.38 , increasing by 8.29 . The number of students completed from 11 to 28 , from the value of 60 to 70, increasing by 10 points. The highest score of 90 to 95 , increased by 5 points.
\end{abstract}

\section{Keywords: Implementation Of Group Guidance, Science Learning Achievement.}

\section{PENDAHULUAN}

Mata pelajaran IPA merupakan bagian dari program pembelajaran yang harus dilaksanakan di SMP. Melalui pembelajaran IPA diharapkan siswa dapat memperoleh pengetahuan yang berhubungan dengan makhluk hidup untuk diterapkan dalam kehidupan sehari-hari.

Namun kenyataan yang dijumpai di SMP N 1 SAWIT menunjukkan masih ada beberapa siswa yang prestasi belajar IPA masih rendah yaitu belum dapat memperoleh prestasi belajar sesuai batas ketuntasan belajar tersebut. Oleh karena itu diperlukan upaya bimbingan belajar kepada siswa yang mengalami kesulitan tersebut sehingga memiliki kesempatan memperoleh prestasi belajar sesuai batas ketuntasan belajar.

\section{Identifikasi Masalah}

Dengan memperhatikan latar belakang masalah tersebut diatas, maka dapat diidentifikasi masalah sebagai berikut:

1. Kurang tepatnya penggunaan media pembelajaran IPA yang telah tersedia.

2. Kurangnya bimbingan belajar kepada siswa yang prestasi belajarnya masih dibawah ketuntasan belajar.

3. Kurang tepatnya metode mengajar yang digunakan dalam pembelajaran IPA.
4. Belum secara maksimal memanfaatkan lingkungan sebagai media belajar IPA.

5. Pelaksanaan evaluasi hasil belajar setiap satu satuan pembelajaran IPA yang belum terkoordinasi.

\section{Perumusan Masalah}

Berdasarkan hasil Identifikasi dan pembatasan masalah tersebut di atas, maka dapat dirumuskan masalah sebagai berikut :

"Apakah Implementasi bimbingan kelompok dapat digunakan sebagai usaha untuk meningkatkan prestasi belajar IPA materi pernapasan pada siswa kelas VIII B SMP N 1 SAWIT semester Genap tahun pelajaran 2017/2018?"

\section{Tinjauan Pustaka}

\section{Bimbingan belajar}

Koestoer Partowisastro (2005:12) menyatakan bahwa"Bimbingan belajar adalah bantuan dalam belajar yang diberikan pada seseorang agar dapat mengembangkan potensi yang dimiliki, mengenali dirinya sendiri, mengatasi persoalan sehingga dapat menentukan sendiri jalan hidupnya secara bertanggung jawab".

2. Jenis-jenis Bimbingan Belajar

a) Bimbingan secara individual

b) Bimbingan secara kelompok 
c) Bimbingan secara Klasikal

\section{Mata Pelajaran IPA}

Boediono (2004:129) menyatakan "IPA atau Ilmu Alam atau Ilmu Pasti merupakan hasil kegiatan manusia berupa pengetahuan, gagasan dan konsep yang terorganisasi tentang kehidupan, alam dan lingkungan makhluk hidup, yang diperoleh dari pengalaman melalui serangkaian proses ilmiah".

\section{Prestasi Belajar}

Sutratinah Tirtonagoro (2009:44) menyatakan "Prestasi belajar adalah hasil usaha kegiatan belajar mengajar yang dinyatakan dalam bentuk simbol, angka, huruf maupun kalimat yang dapat mencerminkan hasil yang dicapai oleh setiap anak dalam periode tertentu".

\section{Kerangka Pemikiran}

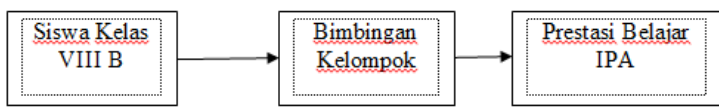

\section{METODOLOGI PENELITIAN}

\section{Subyek Penelitian}

Populasi dalam penelitian ini diambil dari seluruh siswa kelas VIII B semester genap tahun pelajaran 2017/2018 SMP N 1 Sawit, sebanyak 32 siswa dengan jumlah laki-laki 17 anak dan perempuan 15 anak. Subyek penelitian ini dipilih dengan alasan pada ulangan harian Standar Kompetensi Sistem Pernapasan. Kompetensi Dasar pernapasan, ternyata jumlah siswa yang prestasinya paling rendah dibanding dengan kelas yang lain terdapat di kelas VIII B dan proses pembelajarannya belum baik.

\section{Sumber Data}

1. Berdasarkan cara memperolehnya di bagi 2 cara : langsung dan tidak langsung

2. Berdasarkan bentuk data dibagi 2: angka dan bukan angka

3. Berdasarkan banyaknya sumber data, dibagi menjadi 3 yaitu :

a. Data kondisi awal: daftar nila dan catatan proses kegiatan

b. Data siklus I

1) Data proses pembelajaran: lembar observasi dan pengamatan proses belajar

Jurnal Pendidikan Mandala
2) Data hasil pembelajaran: butir soal dan tes tertulis

c. Data siklus II

1) Proses pembelajaran: lembar observasi

2) Hasil pembelajaran: butir soal dan test.

Teknik dan Alat Pengumpul Data

1. Teknik Pengumpulan Data: non test dan test

2. Alat Pengumpul Data: Dokumen wali kelas, Lembar observasi siklus I\&II

\section{HASIL TINDAKAN DAN \\ PEMBAHASAN \\ Deskripsi Prasiklus (Tindakan Awal) \\ 1. Hasil Belajar}

Sebagai langkah awal dilakukan proses pembelajaran dengan menerapkan metode diskusi kelompok, setelah kegiatan pembelajaran dari materi sistem pernapasan diadakan ulangan harian, aktivitas siswa tersebut diperoleh hasil seperti pada tabel dan grafik berikut:

Rata-rata Nilai Ulangan Harian Kondisi Awal

\begin{tabular}{|c|c|c|c|}
\hline NO & URAIAN & UH & Keterangan \\
\hline 1 & $\begin{array}{l}\text { Nilai } \\
\text { Tertinggi }\end{array}$ & 90 & \multirow{5}{*}{$\begin{array}{c}\text { Batas Tuntas } \\
75\end{array}$} \\
\hline 2 & $\begin{array}{l}\text { Nilai } \\
\text { Terendah }\end{array}$ & 60 & \\
\hline 3 & Nilai Rerata & 71.09 & \\
\hline 4 & $\begin{array}{l}\text { Rentang Nilai } \\
\text { Rata-rata }\end{array}$ & 30 & \\
\hline 5 & $\begin{array}{l}\text { Jumlah siswa } \\
\text { tuntas rata- } \\
\text { rata }\end{array}$ & 11 & \\
\hline
\end{tabular}

Daftar Pengamatan Kreativitas dan Motivasi

Belajar Siswa

(Aktivitas Siswa yang Relevan) Pada Tindakan Awal

\begin{tabular}{|l|l|c|c|c|c|c|c|}
\hline No & Kriteria & A & B & C & D & E & Rerata \\
\hline 1 & $\begin{array}{l}\text { Baik } \\
\text { sekali }\end{array}$ & $\mathbf{1 2 . 5} \%$ & $\mathbf{3 . 1} \%$ & $\mathbf{1 5 . 6} \%$ & $\mathbf{0 . 0} \%$ & $\mathbf{6 . 3} \%$ & $\mathbf{7 . 5} \%$ \\
\hline 2 & Baik & $\mathbf{5 0 . 0} \%$ & $\mathbf{2 5 . 0} \%$ & $\mathbf{3 1 . 3} \%$ & $\mathbf{4 6 . 9 \%}$ & $\mathbf{3 7 . 5 \%}$ & $\mathbf{3 8 . 1} \%$ \\
\hline 3 & Sedang & $\mathbf{2 8 . 1} \%$ & $\mathbf{5 9 . 4} \%$ & $\mathbf{3 4 . 4 \%}$ & $\mathbf{3 1 . 3} \%$ & $\mathbf{4 6 . 9} \%$ & $\mathbf{4 0 . 0} \%$ \\
\hline 4 & Kurang & $\mathbf{9 . 4} \%$ & $\mathbf{1 2 . 5} \%$ & $\mathbf{1 8 . 8} \%$ & $\mathbf{2 1 . 9} \%$ & $\mathbf{9 . 4 \%}$ & $\mathbf{1 4 . 4} \%$ \\
\hline
\end{tabular}

\section{Deskripsi Siklus 1}

Hasil pengamatan dipaparkan pada tabel berikut:

Nilai Ulangan Harian Siklus 1

\begin{tabular}{|c|l|c|c|}
\hline NO & URAIAN & UH & KETERANGAN \\
\hline 1 & Nilai & 90 & \multicolumn{1}{|c}{} \\
\cline { 1 - 3 }
\end{tabular}




\begin{tabular}{|c|c|c|c|}
\hline & Tertinggi & & \multirow{5}{*}{ Batas Tuntas 75} \\
\hline 2 & $\begin{array}{l}\text { Nilai } \\
\text { Terendah }\end{array}$ & 70 & \\
\hline 3 & $\begin{array}{l}\text { Nilai } \\
\text { Rata-rata }\end{array}$ & 77.19 & \\
\hline 4 & $\begin{array}{l}\text { Rentang } \\
\text { Nilai }\end{array}$ & 20 & \\
\hline 5 & $\begin{array}{l}\text { Jumlah } \\
\text { siswa } \\
\text { tuntas }\end{array}$ & 23 & \\
\hline
\end{tabular}

Daftar Pengamatan Kreativitas dan Motivasi Belajar Siswa

(Aktivitas Siswa yang Relevan)

Pada Tindakan Siklus 1

\begin{tabular}{|c|l|r|r|r|c|c|c|}
\hline No & Kriteria & A & B & C & D & E & Rerata \\
\hline 1 & $\begin{array}{l}\text { Baik } \\
\text { sekali }\end{array}$ & $18.8 \%$ & $9.4 \%$ & $18.8 \%$ & $12.5 \%$ & $6.3 \%$ & $13.1 \%$ \\
\hline 2 & Baik & $53.1 \%$ & $46.9 \%$ & $40.6 \%$ & $56.3 \%$ & $56.3 \%$ & $50.6 \%$ \\
\hline 3 & Sedang & $\mathbf{2 8 . 1} \%$ & $43.8 \%$ & $37.5 \%$ & $31.3 \%$ & $31.3 \%$ & $34.4 \%$ \\
\hline 4 & Kurang & $0.0 \%$ & $0.0 \%$ & $3.1 \%$ & $0.0 \%$ & $6.3 \%$ & $1.9 \%$ \\
\hline
\end{tabular}

Deskripsi Siklus II

Proses pembelajaran pada siklus II dapat dilihat pada tabel berikut:

Nilai Ulangan Harian Siklus II

\begin{tabular}{|c|l|c|c|}
\hline NO & \multicolumn{1}{|c|}{ URAIAN } & UH & KETERANGAN \\
\hline 1 & Nilai Tertinggi & 95 & \\
\hline 2 & Nilai Terendah & 70 & \multirow{2}{*}{ Batas Tuntas 75 } \\
\hline 3 & Nilai Rerata & 79.38 & \\
\hline 4 & Rentang Nilai Rata-rata & 25 & \\
\hline 5 & Jumlah siswa tuntas rata-rata & 28 & \\
\hline
\end{tabular}

Daftar Pengamatan Kreativitas dan Motivasi Belajar Siswa

(Aktivitas Siswa yang Relevan) Pada Tindakan Siklus II

\begin{tabular}{|c|l|c|c|c|c|c|c|}
\hline No & Kriteria & A & B & C & D & E & Rerata \\
\hline 1 & $\begin{array}{l}\text { Baik } \\
\text { sekali }\end{array}$ & $\mathbf{3 4 . 4} \%$ & $\mathbf{3 4 . 4} \%$ & $\mathbf{3 7 . 5} \%$ & $\mathbf{2 8 . 1} \%$ & $\mathbf{1 5 . 6 \%}$ & $\mathbf{3 0 \%}$ \\
\hline 2 & Baik & $\mathbf{4 6 . 9} \%$ & $\mathbf{3 7 . 5} \%$ & $\mathbf{3 1 . 3} \%$ & $\mathbf{5 6 . 3} \%$ & $\mathbf{5 9 . 4 \%}$ & $\mathbf{4 6 \%}$ \\
\hline 3 & Sedang & $\mathbf{1 8 . 8} \%$ & $\mathbf{2 8 . 1} \%$ & $\mathbf{3 1 . 3} \%$ & $\mathbf{1 5 . 6 \%}$ & $\mathbf{2 5 . 0 \%}$ & $\mathbf{2 4} \%$ \\
\hline 4 & Kurang & $\mathbf{0} \%$ & $\mathbf{0} \%$ & $\mathbf{0} \%$ & $\mathbf{0} \%$ & $\mathbf{0} \%$ & $\mathbf{0} \%$ \\
\hline
\end{tabular}

Sumber data : Hasil Pengamatan

kreativitas siswa siklus II

\section{Pembahasan}

\section{Pembahasan Tindakan}

Pada kondisi awal dalam proses pembelajaran belum menerapkan bimbingan kelompok. Pada proses siklus I dalam pembelajaran IPA telah diterapkan bimbingan kelompok dan dilanjutkan pada proses siklus II dengan menindaklanjuti kekurangan-kekurangan yang masih ditemukan pada siklus I untuk mengoptimalkan penerapan metode.
2. Pembahasan hasil belajar

Peningkatan Prestasi Belajar Dari Tindakan Awal, Siklus I, Siklus II

\begin{tabular}{|c|l|c|c|c|}
\hline NO & \multicolumn{1}{|c|}{ URAIAN } & Prasiklus & Siklus 1 & Siklus II \\
\hline 1 & Nilai Tertinggi & 90 & 90 & 95 \\
\hline 2 & Nilai Terendah & 60 & 70 & 70 \\
\hline 3 & Rentang Nilai & 30 & 20 & 25 \\
\hline 4 & Nilai Rerata & 71.09 & 77.19 & 79.38 \\
\hline 5 & Jml Siswa Tuntas & 11 & 23 & 28 \\
\hline
\end{tabular}

Peningkatan Prestasi Belajar dari Tindakan Awal, Siklus I, Siklus II

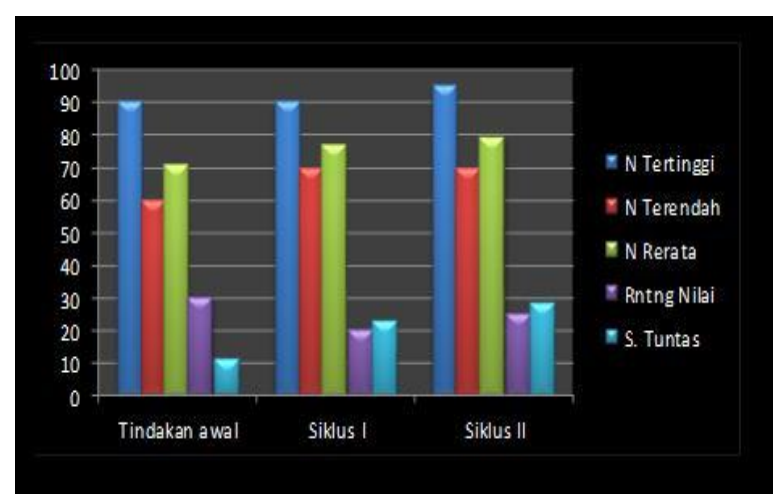

Peningkatan Kreativitas dan Motivasi Belajar Dari Tindakan Awal, Siklus I, Siklus II

\begin{tabular}{|c|l|c|c|c|} 
NO & Kriteria & Prasiklus (\%) & Siklus I (\%) & Siklus II (\%) \\
\hline 1 & Baik Sekali & 7.5 & 13.1 & 30 \\
\hline 2 & Baik & 38.1 & 50.6 & 46 \\
\hline 3 & Sedang & 40 & 34.4 & 24 \\
\hline 4 & Kurang & 14.4 & 1.9 & 0 \\
\hline
\end{tabular}

Peningkatan Kreativitas dan Motivasi Belajar Dari Tindakan Awal, Siklus I, Siklus II

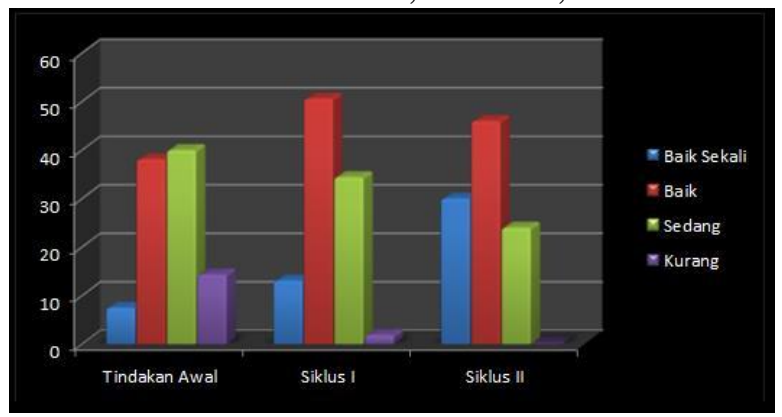

\section{Kesimpulan}

1. Kesimpulan dari siklus I

a. Dengan mengadakan bimbingan kelompok dapat meningkatkan hasil prestasi belajar siswa kelas VIII B semester genap SMP N 1 Sawit tahun 2017/2018 pada standar kompetensi sistem pernapasan.

b. Dengan bimbingan kelompok dapat meningkatkan kreativitas dan motivasi belajar siswa kelas VIII B semester genap SMP N 1 Sawit tahun 
2017/2018 pada standar kompetensi sistem pernapasan.

2. Kesimpulan Siklus II

a. Dengan bimbingan kelompok dapat lebih meningkatkan hasil prestasi belajar siswa kelas VIII B semester genap SMP N 1 Sawit tahun 2017/2018 pada standar kompetensi sistem pernapasan

b. Dengan bimbingan kelompok dapat lebih meningkatkan kreativitas dan motivasi belajar siswa kelas VIII B semester II SMP N 1 Sawit tahun 2017/2018 pada standar kompetensi sistem pernapasan.

\section{DAFTAR PUSTAKA}

Agus, Purwadi. 2010. Modul Pendidikan dan Latihan Profesi Guru Pelatihan Tindakan Kelas. Surakarta: Panitia Sertifikasi Guru Rayon 13 UNS

Boediono, 2004. Hakekat IPA dan Pembelajaran IPA

Bima, Walgito. 2009. Jenis-jenis Bimbingan Belajar. Jakarta: University Press

Chasiyan. 2008. Pelaksanaan Bimbingan Belajar. Jakarta: University Press

Dewa Ketut Sukardi. 2008. Metode Pembelajaran. Surabaya: University Press

Djunihur. 2005. Metode Pembelajaran.Jogjakarta: University Press

Djauzali, Ahmad. 2004. Hakekat Belajar IPA. Jogjakarta: Multi Pressindo

Djarwanto P.S. 2008. Penelitian Tindakan Kelas. Surakarta: University Press

Heribertus, Sugiyanto. 2006. Penelitian Tindakan Kelas. Surakarta: University Press

Hadari, Nawawi. 2005. Penelitian Karya Ilmiah. Surakarta: University Press

Koestor, Partowisastro. 2005. Metode Pembelajaran. Surakarta: University Press

M Ngalim Purwanto. 2007. Evaluasi Pembelajaran. Jogjakarta: Multi Pressindo

Manase, Malo. 2005. Penulisan Karya Ilmiah. Jogjakarta: University Press
Nana, Sudjana. 2009. Metode Pembelajaran IPA. Surabaya: University Press

Prawoto, 2003. Ilmu Pengetahuan Alam dan Sekitarnya. Jogjakarta Press

Sutrisno, Hadi. 2002. Metode Pembelajaran. Jogjakarta: Multi Pressindo

Sumadi, Suryabrata. 2010. Evaluasi Pembelajaran Jogjakarta: University Press

Sutrantinah, Tirtonegoro. 2009. Belajar dan Tehnik Pembelajaran. Jogjakarta: University Press

Suharsimi, Arikunto. 2006. Karya Ilmiah. Jakarta: University Press

W.S. Wingkel. 2001. Belajar dan Pembelajaran. Surabaya: University Press

Zaenal, Arifin. 2008. Penelitian Tindakan Kelas. Yogjakarta: University Press 